\title{
PENGARUH STRATEGI PEMBELAJARAN DAN MOTIVASI BERPRESTASI TERHADAP HASIL BELAJAR TEKNOLOGI INFORMASI DAN KOMUNIKASI
} (TIK)

\author{
Etsas Brema Sinulingga ${ }^{1}$,Harun Sitompul ${ }^{2}$, Asih Menanti ${ }^{3}$ \\ ${ }^{1}$ Sekolah Menengah Atas Negeri 1 Bilah Hulu, Sumatera Utara \\ ${ }^{2,3}$ Pascasarjana, Universitas Negeri Medan \\ Etsas_brema@gmail.com ${ }^{l}$
}

\begin{abstract}
Abstrak: Penelitian ini bertujuan untuk mengetahui pengaruh Strategi Pembelajaran dan Motivasi Berprestasi terhadap hasil belajar TIK siswa. Populasi penelitian ini adalah seluruh siswa kelas XI SMA Negeri 1 Bilah Hulu, yang terdiri dari 4 kelas dengan jumlah 163 siswa. Teknik pengambilan sampel dengan cluster random sampling. Data penelitian dikumpul dengan menggunakan tes untuk hasil belajar TIK dan angket Motivasi Berprestasi. Analisis data dilakukan dengan anava dua jalur pada taraf signifikansi 5\%. Hasil penelitian diperoleh hasil sebagai berikut: (1) hasil belajar TIK kelompok siswa yang diberi pembelajaran dengan Strategi Pembelajaran Problem Based Learning lebih tinggi dibandingkan hasil belajar kelompok siswa yang diberi pembelajaran dengan Strategi Pembelajaran Think Pair Share dengan nilai Fhitung 7,30 > FTabel 3,96; (2) hasil belajar TIK kelompok siswa yang memiliki Motivasi Berprestasi Tinggi lebih tinggi dibandingkan hasil belajar kelompok siswa yang memiliki Motivasi Berprestasi Rendah dengan nilai Fhitung $=16,79>$ FTabel $=3,96$; (3) terdapat interaksi antara Strategi Pembelajaran dan Motivasi Berprestasi dalam mempengaruhi hasil belajar TIK dengan nilai FHitung kolom - baris (interaksi) lebih besar dari FTabel (FHitung = 12,64 > FTabel = 3,96) pada taraf signifikansi 5\%.
\end{abstract}

Kata Kunci: problem based learning, preview question read reflect recite review, motivasi berprestasi, teknologi informasi dan komunikasi

\begin{abstract}
This study aims to determine the effect of Learning Strategies and Achievement Motivation on students' ICT learning outcomes. The population of this study was all students of class XI of SMA Negeri 1 Bilah Hulu, consisting of 4 classes with a total of 163 students. The sampling technique is cluster random sampling. Research data were collected using tests for ICT learning outcomes and the Achievement Motivation questionnaire. Data analysis was performed with two-way anova at a significance level of 5\%. The results obtained are as follows: (1) ICT learning outcomes of groups of students who are given learning with Problem Based Learning Learning Strategies are higher than the learning outcomes of groups of students who are taught learning with Think Pair Share Learning Strategies with Fcount value of 7.30> FTabel 3, 96; (2) ICT learning outcomes of groups of students who have High Achievement Motivation are higher than learning outcomes of groups of students who have Low Achievement Motivation with Fcount $=$ 16.79> FTabel = 3.96; (3) there is an interaction between Learning Strategies and Achievement Motivation in influencing ICT learning outcomes with the F value of column count (row) is greater than FTabel (Fcount $=12.64>$ FTabel $=3.96$ ) at the 5\% significance level.
\end{abstract}

Keywords: problem based learning, preview question read reflect recite review, achievement motivation, information and communication technology

\section{PENDAHULUAN}

Salah satu unsur yang turut menentukan kualitas Sumber Daya Manusia adalah penguasaan Teknologi Informasi dan Komunikasi (TIK). Sekolah Menengah Atas (SMA) sebagai salah satu lembaga pendidikan menengah perlu membekali siswa dan lulusannya dengan keterampilan yang memadai termasuk kompetensi TIK. Oleh sebab itu, TIK dijadikan sebagai salah satu mata pelajaran di Sekolah khususnya pada jenjang pendidikan Sekolah Menengah Atas (SMA).
Badan Penelitian dan Pengembangan Pusat Kurikulum Depdiknas (2003:1) menyatakan bahwa Teknologi Informasi dan Komunikasi mempunyai pengertian dari dua aspek, yaitu teknologi informasi dan teknologi komunikasi. Teknologi informasi mempunyai pengertian luas yang meliputi segala hal yang berkaitan dengan proses, penggunaan alat bantu, manipulasi dan pengelolaan informasi. Teknologi komunikasi mempunyai pengertian segala hal yang berkaitan dengan penggunaan alat bantu untuk memproses dan 
mentransfer data dari perangkat yang satu ke yang lainnya. Karena itu teknologi informasi dan komunikasi adalah suatu padanan yang tidak terpisahkan yang mengandung pengertian luas tentang segala aspek yang berkaitan dengan pemrosesan.

Teknologi Informasi dan Komunikasi (TIK) merupakan terminologi yang digunakan untuk melingkupi alat yang dipakai guna meningkatkan kemampuan manusia dalam berkomunikasi dan pengolahan data. TIK merupakan suatu padanan yang tidak dapat terpisahkan, memuat pengertian luas dalam aspek yang terkait dengan pemprosesan, manipulasi, pengelolaan, dan transfer/pemindahan informasi antar media menggunakan teknologi tertentu (Puskur Balitbang, Depdiknas, 2003 dalam Haryono). Melalui pembelajaran TIK siswa diarahkan agar mampu menggunakan perangkat TIK dalam upaya pencarian, eksplorasi, analisis, dan saling tukar informasi secara kreatif dan bertanggung jawab.

Visi mata pelajaran TIK, yaitu siswa dapat menggunakan perangkat TIK secara tepat dan optimal untuk mendapatkan dan memproses informasi dalam kegiatan belajar, bekerja dan beraktifitas lainnya, sehingga siswa mampu berkreasi, mengembangkan sikap inisiatif, mengembangkan kemampuan eksplorasi, dan mudah beradaptasi dengan perkembangan yang baru (Depdiknas 2003: 2). Penerapan mata pelajaran TIK akan membentuk siswa untuk belajar teknologi informasi dan komunikasi dan menggunakan segala potensi yang ada untuk pengembangan kemampuan diri.

Menurut Depdiknas (2003:3) menjelaskan bahwa teknologi informasi dan komunikasi secara umum bertujuan agar siswa memahami alat teknologi informasi dan komunikasi secara umum termasuk komputer (computer literate) dan memahami informasi (information literate), artinya siswa mengenal istilah-istilah yang digunakan pada teknologi informasi dan komunikasi dan istilah-istilah pada komputer yang umum digunakan. Siswa juga menyadari keunggulan dan keterbatasan komputer secara optimal.

SMA Negeri 1 Bilah Hulu Kabupaten Labuhan Batu adalah salah satu Sekolah Menengah Atas (SMA) yang memiliki mata pelajaran TIK. TIK sebagai salah satu mata pelajaran yang diterapkan di Sekolah khususnya di SMA Negeri 1 Bilah Hulu Kabupaten Labuhan Batu memiliki kesulitan tersendiri dalam penyampaiannya terhadap siswa.Informasi ini diperoleh berdasarkan hasil wawancara dengan guru mata pelajaran TIK dan observasi studi dokumen yang telah dilakukan oleh peneliti pada bulan Mei tahun 2016 di kelas XI SMA Negeri 1 Bilah Hulu Kabupaten Labuhan Batu.

Keterangan yang diberikan oleh guru adalah hasil belajar TIK dan gairah belajar siswa masih rendah. Siswa belum menunjukkan ketertarikannya dalam mempelajari materi TIK. Hal ini dikemukakan oleh guru dengan memperhatikan kegiatan sehari-hari siswa selama proses pembelajaran TIK dimana siswa kurang mempersiapkan diri setiap kali pembelajaran TIK akan dilaksanakan. Masih banyak siswa yang tidak membawa buku pelajaran TIK ke Sekolah. Selain itu, tidak jarang ditemui siswa yang kurang mendengarkan dan memperhatikan penjelasan guru ketika mengajar sehingga guru sering memberikan sanksi dengan membuat siswa tersebut berdiri di depan kelas. Beberapa arahan guru kepada siswa agar melengkapi sarana belajar dengan menyediakan ragam buku pelajaran juga kurang ditanggapi oleh siswa. Hal ini terlihat dari sikap siswa yang sering meminjam buku TIK temannya yang berbeda kelas.

Rendahnya kualitas pembelajaran TIK akan berdampak pada rendahnya hasil belajar TIK yang diperoleh siswa dan keaktifan siswa selama mengikuti pembelajaran. Oleh sebab itu, sangatlah penting memperhatikan faktor-faktor yang mempengaruhi hasil belajar siswa agar dapat melakukan proses pembelajaran yang berkualitas. Slameto (2009:54) menyebutkan faktor-faktor yang mempengaruhi hasil belajar digolongkan menjadi dua, yaitu faktor eksternal dan faktor internal. Adapun yang dimaksud dengan faktor eksternal adalah segala faktor yang berasal dari luar diri siswa seperti faktor keluarga, faktor sekolah dan faktor masyarakat.

Dalam hal ini rendahnya hasil belajar Teknologi Informasi dan Komunikasi siswa apabila ditinjau dari sisi eksternal siswa salah satunya berkaitan dengan sekolah sebagai lembaga pendidikan yang mencakup strategi pembelajaran, kurikullum dan waktu sekolah. Oleh sebab itu, perlu pengkajian khusus mengenai strategi pembelajaran yang digunakan. Apakah strategi tersebut sesuai 
dengan konteks materi dan tujuan pembelajaran, potensi dan latar belakang siswa serta konteks dengan situasi dan lingkungan belajar. Oleh karena itu, guru memiliki peran yang sangat penting terutama yang menyangkut strategi pembelajaran yang digunakan dalam proses belajar yang juga akan ikut menentukan tinggi-rendahnya hasil dan tercapainya tujuan pembelajaran TIK.

Untuk menggali potensi siswa agar selalu kreatif perlu diterapkan pembelajaran bermakna yang akan membawa siswa pada pengalaman belajar yang mengesankan. Pengalaman yang diperoleh siswa semakin berkesan apabila proses pembelajaran yang diperoleh merupakan hasil dari pemahaman dan penemuannya sendiri yaitu proses yang melibatkan siswa sepenuhnya untuk merumuskan suatu konsep. Untuk itu sudah menjadi tugas guru dalam mengelola proses belajar-mengajar adalah memilih strategi pembelajaran yang sesuai, agar pembelajaran lebih menarik dan bermakna. Salah satu strategi pembelajaran yang dapat memberikan situasi belajar yang kondusif, mengaktifkan siswa serta dapat meningkatkan gairah belajar siswa adalah strategi pembelajaran Problem Based Learning (PBL).

Ali (2009:72) menjelaskan bahwa Problem Based Learning (PBL) adalah strategi belajar yang menggunakan masalah sebagai langkah awal dalam mengumpulkan dan mengintegrasikan pengetahuan baru. Atau menurut Boud \& Felleti seperti dikutip Ali (2009:72) menyatakan bahwa " Problem Based Learning is a way of constructing and teaching course using problem as a stimulus and focus on student activity". (Problem Based Learning adalah sebuah cara untuk membangun dan mengajar dengan menggunakan masalah sebagai rangsangan dan pusat aktivitas siswa). Dengan demikian, strategi pembelajaran Problem Based Learning merupakan salah satu dari berbagai strategi pembelajaran yang dapat digunakan guru dalam mengaktifkan siswa dalam belajar.

Strategi pembelajaran berdasarkan masalah bercirikan penggunaan masalah dunia nyata. Strategi ini dapat digunakan untuk meningkatkan keterampilan berpikir kritis dan keterampilan memecahkan masalah serta untuk mendapatkan pengetahuan tentang konsepkonsep penting. Strategi pembelajaran ini mengutamakan proses belajar, tugas guru harus memfokuskan diri untuk membantu siswa mencapai keterampilan mengarahkan diri.

Strategi pembelajaran Problem Based Learning (PBL) menyuguhkan suasana belajar yang variatif. Selain mengkondisikan siswa dalam kegiatan berdiskusi, strategi pembelajaran PBL juga mengawali penyajian pembelajaran dengan contoh masalah yang mengaitkan materi pelajaran dengan aplikasinya terhadap situasi nyata. Kondisi ini sangat sesuai dengan tujuan pembelajaran TIK seperti yang dikemukakan oleh Depdiknas (2003:4) yaitu mengembangkan kemampuan belajar yang berinisiatif, inovatif, kreatif, dan bertanggungjawab dalam penggunaan teknologi informasi dan komunikasi untuk pembelajaran, pekerjaan, dan pemecahan masalah.

Lebih lanjut, kondisi yang tercipta pada pembelajaran dengan strategi pembelajaran PBL juga sesuai dengan lingkup pembelajaran TIK yang dikemukakan oleh Depdiknas (2003:8) yaitu aspek pemecahan masalah, eksplorasi dan komunikasi di dalamnya mencakup pembuatan karya dengan program pengolahan data dan lembar kerja pembuatan karya dengan program persentasi data base. Kondisi yang diciptakan oleh strategi pembelajaran Problem Based Learning membuat siswa aktif dan bergairah dalam belajar sehingga hasil belajar yang dicapai siswa akan lebih optimal. Hal senada juga dikemukakan oleh Semiawan seperti dikutip oleh Haryono (1998:23) yang menjelaskan bahwa

Proses pembelajaran TIK perlu dikembangkan dalam bentuk pengalaman dialogis yang ditandai oleh situasi belajar yang bercirikan pengalaman dua sisi. Kondisi inilah yang sangat dibutuhkan dalam kegiatan pembelajaran pada mata pelajaran TIK. Siswa yang menganggap materi pelajaran ini menjenuhkan akan merubah siswa menjadi lebih aktif dibandingkan guru dan dapat membentuk sendiri pengetahuan mereka. Melalui rangkaian kegiatan siswa yang direncanakan melalui strategi pembelajaran Problem Based Learning dapat membantu siswa dalam menghadapi setiap kelemahannya dalam mempelajari mata pelajaran TIK karena semua siswa akan saling berinteraksi dan bekerjasama dalam memecahkan masalah pembelajaran yang mereka temukan.

Beberapa penelitian terdahulu yang relevan dengan kajian masalah dalam penelitian 
ini juga menyimpulkan hasil penelitian yang menunjukkan kualitas strategi pembelajaran Problem Based Learning. Diantaranya seperti yang dilakukan oleh Bekti dan Herman (2013) dalam penelitiannya menyimpulkan bahwa terdapat perbedaan hasil belajar siswa pada mata pelajaran pemrograman sistem kendali PLC yang signifikan antara siswa yang diajar dengan strategi pembelajaran Problem Based Learning (PBL) dengan siswa yang diajar dengan strategi pembelajaran konvensional. Hasil belajar siswa yang diajar dengan strategi Problem Based Learning lebih tinggi dibandingkan dengan siswa yang diajar dengan strategi pembelajaran Konvensional.

Selanjutnya, Prayekti (2015) dalam penelitiannya juga menyimpulkan bahwa strategi pembelajaran Problem Based Learning (PBL) berpengaruh secara signifikan terhadap hasil belajar siswa dimana siswa yang dibelajarkan dengan strategi Problem Based Learning memiliki hasil belajar yang lebih tinggi dibandingkan dengan siswa yang dibelajarkan dengan strategi ekspositori.

Kondisi berbeda yang terjadi dengan penerapan strategi pembelajaran konvensional yang biasa diterapkan di SMA Negeri 1 Bilah Hulu Kabupaten Labuhan Batu yaitu strategi pembelajaran PQ4R (Preview - Question Read - Reflect - Recite - Review). Strategi pembelajaran ini juga memberikan kondisi pembelajaran yang turut membangun keaktifan dan kreativitas siswa dalam belajar. Trianto (2007:89) menjelaskan bahwa strategi PQ4R adalah strategi yang digunakan untuk membantu siswa mengingat apa yang mereka baca dan dapat membantu proses belajar mengajar di kelas yang dilaksanakan dengan kegiatan membaca buku. Strategi pembelajaran PQ4R mengajak siswa membentuk pengetahuannya melalui keterampilan membaca. Pemilihan strategi ini berlandaskan pertimbangan dengan keterampilan membaca setiap siswa akan dapat memasuki dunia keilmuan TIK, memahami khasanah kearifan yang banyak hikmat, dan mengembangkan berbagai keterampilan lainnya yang amat berguna untuk mencapai sukses dalam pembelajaran TIK. Siswa akan beraktivitas membaca buku melalui tahapan-tahapan. Kondisi yang diciptakan oleh strategi pembelajaran $\mathrm{PQ} 4 \mathrm{R}$ ini diperlukan dalam mempelajari setiap materi pada mata pelajaran TIK.
Bervariasinya informasi dan sumber belajar TIK membuat siswa harus sering beraktivitas dalam belajar melalui keterampilan membaca. Akan tetapi, berdasarkan karakteristik dari pembelajaran TIK yang mengharuskan setiap siswa dapat mengembangkan potensi diri untuk dapat berkreasi, inovatif dan bertanggungjawab dalam penggunaan teknologi informasi dan komunikasi untuk pembelajaran, pekerjaan, dan pemecahan masalah akan sulit dicapai. Aspek pemecahan masalah, eksplorasi dan komunikasi dalam lingkup pembelajaran TIK akan sulit digapai dikarenakan pada strategi pembelajaran $\mathrm{PQ} 4 \mathrm{R}$, kemampuan pemecahan masalah dan komunikasi antar siswa kurang terjalin.

Setelah mengkaji faktor eksternal di atas, faktor internal siswa juga turut menjadi bagian penting dalam menentukan kualitas hasil belajar siswa. Faktor internal adalah faktor yang berasal dari dalam diri siswa seperti motivasi, minat, bakat dan inteligensi siswa. Dalam hal ini yang akan dikaji adalah faktor motivasi sebagai faktor yang berasal dari dalam diri siswa. Salah satu bentuk motivasi siswa adalah motivasi berprestasi. Motivasi berprestasi pertama kali diperkenalkan oleh Murray seperti dikutip oleh Khoe (2015:352) yang diistilahkan dengan Need for Achievement dan dipopulerkan oleh Mc Clelland dengan sebutan " $n$-ach", yang beranggapan bahwa motif berprestasi merupakan virus mental sebab merupakan pikiran yang berhubungan dengan cara melakukan kegiatan dengan lebih baik daripada cara yang pernah dilakukan sebelumnya.

Menurut Dimyati (2014:86) motivasi berprestasi ini sangat penting dalam kehidupan sehari-hari, karena motif berprestasi akan mendorong seseorang untuk mengatasi tantangan atau rintangan dan memecahkan masalah seseorang, bersaing secara sehat, serta akan berpengaruh pada prestasi seseorang. Atkinson seperti dikutip oleh Djaali (2008:107) mengatakan bahwa motivasi berprestasi dalam perilaku individu mengandung dua kecenderungan perilaku, yaitu: (a) Individu yang cenderung mengejar atau mendekati kesuksesan dan (b) Individu yang berusaha untuk menghindari kegagalan.

Faktor motivasi berprestasi siswa dalam pembelajaran TIK sangatlah penting. Hal ini mengacu kepada salah satu tujuan khusus pembelajaran TIK seperti yang dikemukakan oleh Depdiknas (2003:4) yaitu memotivasi 
kemampuan siswa untuk beradaptasi dan mengantisipasi perkembangan teknologi informasi dan komunikasi. Hal senada telah diungkap oleh hasil penelitian sebelumnya seperti yang dilakukan oleh Hayatsyah (2005) dalam penelitiannya menyimpulkan bahwa siswa yang memiliki motivasi berprestasi tinggi memiliki hasil belajar yang lebih tinggi dibandingkan dengan siswa yang memiliki motivasi berprestasi rendah.

Siswa yang memiliki motivasi berprestasi tinggi akan mempunyai harapan yang besar untuk sukses dalam belajar. Motivasi yang dimiliki siswa akan membentuk semangat belajar siswa sehingga pencapaian hasil belajar akan lebih optimal. Dengan dimilikinya sikap yang positif terhadap pencapaian tujuan akan menyebabkan siswa berusaha sedemikian mungkin dalam mencapai prestasi tertinggi. Berdasarkan uraian di atas, penulis merasa tertarik untuk melakukan penelitian tentang " Pengaruh Strategi pembelajaran dan Motivasi Berprestasi Siswa Terhadap Hasil belajar Teknologi Informasi dan Komunikasi (TIK) di SMA Negeri 1 Bilah Hulu Kabupaten Labuhan Batu”. Adapun tujuan penelitian ini adalah untuk mengetahui: (1) apakah hasil belajar Teknologi Informasi dan Komunikasi siswa yang diajar dengan strategi pembelajaran Problem Based Learning lebih tinggi dari pada hasil belajar siswa yang diajar dengan strategi pembelajaran PQ4R; (2) apakah hasil belajar Teknologi Informasi dan Komunikasi siswa yang memiliki Motivasi Berprestasi tinggi lebih tinggi dari pada siswa yang memiliki Motivasi Berprestasi rendah; dan (3) interaksi antara strategi pembelajaran dengan Motivasi Berprestasi terhadap hasil belajar Teknologi Informasi dan Komunikasi siswa.

\section{METODE}

Lokasi penelitian ini adalah SMA Negeri 1 Bilah Hulu Kabupaten Labuhan Batu. Populasi dalam penelitian ini adalah seluruh siswa kelas XI pada semester ganjil yang terdiri dari 4 kelas dengan jumlah 163 siswa. Seluruh sampel memiliki karakteristik siswa yang relatif sama, artinya setiap kelas tidak memiliki siswa yang tinggal kelas, tidak ada kelas unggulan, umur rata - rata siswa relatif sama, nilai rata rata kelas relatif sama berdasarkan hasil ulangan harian, sehingga seluruh kelas yang ada dapat diikutkan sebagai populasi dalam penelitian.
Teknik penentuan sampel digunakan teknik cluster random sampling. Sampel yang diambil terdiri dari dua kelas yaitu kelas Eksperimen yang diberi perlakuan dengan strategi pembelajaran Problem Based Learning (PBL) dan kelas kontrol yang diberi perlakuan dengan strategi pembelajaran PQ4R (Preview Question - Read - Reflect - Recite - Review). Dari hasil undian yang terpilih sebagai kelas Eksperimen adalah kelas XI ${ }^{1}$ yang berjumlah 41 siswa dan kelas $\mathrm{XI}^{2}$ sebagai kelas Kontrol yang berjumlah 42 orang. Dengan demikian, seluruh sampel penelitian berjumlah 83 orang. Selanjutnya, sebelum dilakukan eksperimen, kedua sampel terlebih dahulu diberi skala untuk mengetahui motivasi berprestasi siswa.

Metode yang dilakukan dalam penelitian ini adalah metode eksperimental semu ( quasi - experimental research) dengan melakukan eksperimen di dalam kelas yang sudah tersedia sebagaimana adanya tanpa melakukan perubahan situasi kelas dan jadwal pembelajaran, sedangkan karakteristik siswa yang dikontrol adalah motivasi berprestasi. Perlakuan dilaksanakan pada pembelajaran TIK dengan variabel bebas penggunaan strategi pembelajaran yang dibedakan atas strategi pembelajaran Problem Based Learning (PBL) dan strategi pembelajaran PQ4R yang dilakukan oleh guru TIK SMA Negeri 1 Bilah Hulu. Sebelum perlakuan dilaksanakan, terlebih dahulu kedua guru diberikan pengarahan mengenai prosedur pelaksanaan dari strategi pembelajaran PBL dan PQ4R.

Variabel moderator dalam penelitian ini adalah motivasi berprestasi. Variabel ini dibedakan atas motivasi berprestasi tinggi dan motivasi berprestasi rendah. Pengelompokan motivasi berprestasi siswa ini diperoleh berdasarkan skor angket motivasi berprestasi yang disusun dengan menggunakan indikator indikator yang telah standar. Sedangkan sebagai variabel terikat adalah hasil belajar TIK. Skor hasil belajar TIK diperoleh dari hasil tes yang dilakukan dalam bentuk pilihan berganda yang dilaksanakan pada akhir pertemuan setelah perlakuan dilaksanakan.

Penelitian ini menggunakan desain faktorial $2 \times 2$, sebagai variabel bebas pertama adalah penggunaan strategi pembelajaran yang dibedakan atas Strategi Pembelajaran Problem Based Learning (PBL) dan Strategi Pembelajaran PQ4R. Variabel moderator yaitu motivasi berprestasi siswa, dengan pengelompokan motivasi berprestasi tinggi dan 
motivasi berprestasi rendah. Sedangkan variabel terikatnya adalah hasil belajar TIK.

Teknik analisis data dalam penelitian ini menggunakan analisis deskriptif dan analisis inferensial. Teknik analisis deskriptif dimaksudkan untuk mendeskripsikan data penelitian meliputi mean, median, standar deviasi, modus dan median data.

Untuk menguji kebenaran hipotesis yang diajukan dalam penelitian ini, maka teknik analisis data yang digunakan adalah Analisis Varians (Anava) Dua Jalur. Pengunaan teknik ini dengan maksud agar hasil tes akhir yang dicapai oleh subjek penelitian benar - benar karena pengaruh dari perlakuan yang diberikan selama penelitian. Taraf signifikan yang digunakan dalam penelitian ini adalah $\propto=0,05$.

Selanjutnya apabila hasil pengujian menunjukan terdapatnya interaksi maka perlu dilakukan uji lanjut dengan uji Scheffe apabila jumlah siswa (n) tiap sel berbeda atau uji Tuckey apabila jumlah siswa (n) tiap sel sama.

Uji menggunaka ANAVA dua jalur perlu dipenuhi beberapa syarat yaitu : (1) data yang digunakan harus berdistribusi normal dan (2) data harus memiliki varians populasi homogen. Untuk menguji normalitas data digunakan uji Liliefors dan untuk menguji homogenitas varians digunakan

uji Kesamaa Dua Varians dan Uji Bartlett.

Sebelum dilakukan analisis data untuk menguji hipotesis maka data yang diperoleh terlebih dahulu diuji normalitas dan homogenitasnya. Untuk kebutuhan analisis data, maka ada 8 kelompok sampel yang akan diuji normalitas dan homogenitasnya sesuai dengan rancangan penelitian yaitu analisis varians (anava) dua arah $2 \times 2$.

Uji normalitas ini digunakan untuk mengetahui sampel yang digunakan apakah berasal dari populasi yang berdistribusi normal atau tidak. Pengujian dilakukan dengan menggunakan uji Liliefors pada kelompok sampel, adapun kriteria pengujian normalitas ini adalah jika $\mathrm{L}_{o}<\mathrm{L}_{\text {tabel }}$ maka sampel berdistribusi normal dan jika $\mathrm{L}_{\mathrm{o}}>\mathrm{L}_{\text {tabel }}$ maka sampel tidak berdistribusi normal. Rangkuman hasil perhitungan normalitas dapat dilihat pada Tabel 2 berikut:

\section{HASIL DAN PEMBAHASAN Hasil Penelitian}

Untuk data statistik yang diperlukan dalam pengujian dengan anava dua jalur disajikan pada Tabel 4.13 yang meliputi jumlah subjek setiap kelompok $(\mathrm{N})$, jumlah total data $(\Sigma X)$, jumlah kuadrat data $\left(\Sigma X^{2}\right)$, dan nilai rata-rata kelompok subjek $(\bar{X})$, nilai setiap rata-rata setiap kelompok dianalisis untuk menentukan apakah secara statistik nilai ratarata tersebut berbeda secara signifikan atau tidak, nilai-nilai statistik ini dipakai sebagai dasar keputusan menguji statistik nol. Berikut disajikan pada Tabel 1 Data Statistik Penelitian:

Tabel 1 Data Statistik Penelitian

\begin{tabular}{|c|c|c|c|c|}
\hline Motivasi Ber & jaran $(\mathrm{A})$ & $\begin{array}{c}\text { Problem Based } \\
\text { Learning } \\
\left(\mathrm{A}_{1}\right)\end{array}$ & $\begin{array}{c}\text { PQ4R } \\
\left(\mathbf{A}_{2}\right)\end{array}$ & Jumlah \\
\hline & $\mathbf{N}$ & 19 & 22 & 41 \\
\hline Tinggi & $\Sigma X$ & 1615 & 1621 & 3236 \\
\hline$\left(\mathbf{B}_{1}\right)$ & $\Sigma X^{2}$ & 138172,64 & 121056,01 & 259228,65 \\
\hline & $\overline{\bar{X}}$ & 85,01 & 73,69 & 78,94 \\
\hline & $\mathbf{N}$ & 22 & 20 & 42 \\
\hline & $\Sigma \mathbf{X}$ & 1570 & 1439 & 3009 \\
\hline$\left(\mathbf{B}_{2}\right)$ & $\Sigma X^{2}$ & 113425,16 & 104894,40 & 218319,56 \\
\hline & $\overline{\bar{X}}$ & 71,35 & 71,97 & 71,65 \\
\hline & $\mathbf{N}$ & 41 & 42 & 83 \\
\hline & $\Sigma \mathbf{X}$ & 3185 & 3061 & 6245 \\
\hline Jumlah & $\Sigma X^{2}$ & 251597,80 & 225950,41 & 477548,21 \\
\hline & $\bar{X}$ & 77,68 & 72,87 & \\
\hline
\end{tabular}


Berdasarkan hasil perhitungan uji normalitas nilai hasil belajar siswa pada kelompok belajar dengan taraf signifikansi $\alpha=$ 5\% diperoleh nilai $\mathrm{L}_{\text {Hitung }}<\mathrm{L}_{\text {Tabel}}$, sehingga pengujian terhadap distribusi data hasil belajar semua kelompok belajar berasal dari populasi yang berdistribusi Normal dan juga disimpulkan bahwa data hasil belajar kedua kelompok adalah homogen
Kriteria pengujian yang digunakan adalah jika $\mathrm{F}_{\text {Hitung }}$ lebih besar dari $\mathrm{F}_{\text {Tabel }}\left(\mathrm{F}_{\text {Hitung }}>\right.$ $\mathrm{F}_{\text {Tabel }}$ ) pada taraf signifikansi 0,05 maka Ho ditolak dan sebaliknya jika $\mathrm{F}_{\text {Hitung }}<\mathrm{F}_{\text {Tabel }} \mathrm{Ho}$ diterima. Pengujian hipotesis ini dilakukan dengan teknik inferensial anava 2 jalur. Berikut disajikan pada Tabel 6 ringkasan perhitungan anava dua jalur dari hasil penelitian:

Tabel 2. Rangkuman Perhitungan Anava Dua Jalur Data Penelitian

\begin{tabular}{|l|r|r|r|r|r|l|}
\hline \multicolumn{1}{|c|}{ Varians } & Dk & JK & RJK & $\mathbf{F}_{\text {Hitung }}$ & $\mathbf{F}_{\text {Tabel }}$ & \multicolumn{1}{|c|}{ Hipotesis } \\
\hline Antar Baris & 1 & 1102,78 & 1102,78 & 16,79 & 3,96 & $\begin{array}{l}\text { Ho : Tolak } \\
\text { Ha : Terima }\end{array}$ \\
\hline Antar Kolom & 1 & 479,54 & 479,54 & 7,30 & 3,96 & $\begin{array}{l}\text { Ho : Tolak } \\
\text { Ha : Terima }\end{array}$ \\
\hline Kolom-Baris (Interaksi) & 1 & 830,11 & 830,11 & 12,64 & 3,96 & $\begin{array}{l}\text { Ho : Tolak } \\
\text { Ha : Terima }\end{array}$ \\
\hline $\begin{array}{l}\text { Dalam Kelompok } \\
\text { kekeliruan) }\end{array}$ & 79 & 5187,55 & 65,67 & & & \\
\hline Total & 82 & 7599,99 & & & & \\
\hline
\end{tabular}

Berdasarkan Tabel 6 terlihat bahwa nilai $F_{\text {Hitung }}$ antar kolom lebih besar dari $F_{\text {Tabel }}$ $\left(\mathrm{F}_{\text {Hitung }}=7,30>\mathrm{F}_{\text {Tabel }}=3,96\right)$ pada taraf signifikansi 5\%. Dengan demikian Ho ditolak dan Ha diterima. Dengan demikian hipotesis penelitian yang menyatakan kelompok siswa yang diajar dengan menggunakan strategi pembelajaran Problem Based Learning memiliki hasil belajar TIK yang lebih tinggi dibanding kelompok siswa yang diajar dengan menggunakan strategi pembelajaran PQ4R teruji kebenarannya. Dalam hal ini, hasil belajar siswa yang diberi strategi pembelajaran Problem Based Learning lebih baik dari hasil belajar siswa yang diberi strategi pembelajaran PQ4R, dikarenakan nilai rata-rata hasil belajar siswa yang diajar dengan strategi pembelajaran Problem Based Learning lebih tinggi dari nilai rata-rata hasil belajar siswa yang diajar dengan strategi pembelajaran PQ4R.

Berdasarkan Tabel 6 terlihat bahwa nilai $F_{\text {Hitung }}$ antar baris lebih besar dari $F_{\text {Tabel }}$ $\left(\mathrm{F}_{\text {Hitung }}=16,79>\mathrm{F}_{\text {Tabel }}=3,96\right)$ pada taraf signifikansi 5\%. Dengan demikian Ho ditolak dan Ha diterima. Dengan demikian hipotesis penelitian yang menyatakan kelompok siswa yang memiliki motivasi berprestasi tinggi memperoleh hasil belajar TIK yang lebih tinggi dibanding kelompok siswa yang memiliki motivasi berprestasi rendah teruji kebenarannya.

Berdasarkan Tabel 6 terlihat bahwa nilai $\mathrm{F}_{\text {Hitung }}$ kolom - baris (interaksi) lebih besar dari $\mathrm{F}_{\text {Tabel }}\left(\mathrm{F}_{\text {Hitung }}=12,64>\mathrm{F}_{\text {Tabel }}=3,96\right)$ pada taraf signifikansi 5\%. Dengan demikian Ho ditolak dan $\mathrm{Ha}$ diterima yang menyatakan terdapat interaksi antara strategi pembelajaran dan motivasi berprestasi dalam mempengaruhi hasil belajar TIK siswa teruji kebenarannya.

Dikarenakan bahwa terdapat interaksi, maka perlu dilakukan uji lanjut untuk mengetahui hasil belajar mana dari setiap kelompok siswa yang lebih tinggi secara signifikan. Dikarenakan jumlah siswa pada setiap sel berbeda maka uji lanjut dilakukan dengan uji Scheffe. Berikut disajikan pada Tabel 7 rangkuman hasil perhitungan analisis data hipotesis statistik dengan menggunakan uji lanjut Scheffe: 
Tabel 3. Rangkuman Perhitungan Uji Lanjut Scheffe

\begin{tabular}{|l|l|l|l|l|l|}
\hline \multicolumn{1}{|c|}{ Kelompok Kelas } & \multicolumn{1}{|c|}{ RKD } & $\begin{array}{c}\text { RKD } \\
(1 / \mathrm{ni}+1 / \mathrm{nj})\end{array}$ & \multicolumn{1}{|c|}{$\mathbf{F}_{\text {Hitung }}$} & $\mathbf{F}_{\text {Tabel }}$ & \multicolumn{1}{c|}{ Status } \\
\hline Eksperimen dan Kontrol & 65.67 & 3.17 & 7.30 & 2.72 & Ho Ditolak \\
\hline $\begin{array}{l}\text { Motivasi Berprestasi Tinggi dan } \\
\text { Rendah }\end{array}$ & 65.67 & 3.17 & 16.79 & 2.72 & Ho Ditolak \\
\hline $\begin{array}{l}\text { Motivasi Berprestasi Tinggi } \\
\text { Antar Kelas }\end{array}$ & 65.67 & 6.44 & 19.88 & 2.72 & Ho Ditolak \\
\hline $\begin{array}{l}\text { Motivasi Berprestasi Rendah } \\
\text { Antar Kelas }\end{array}$ & 65.67 & 6.27 & 0.06 & 2.72 & Ho Diterima \\
\hline $\begin{array}{l}\text { Motivasi Berprestasi Tinggi dan } \\
\text { Rendah Kelas Kontrol }\end{array}$ & 65.67 & 6.27 & 0.47 & 2.72 & Ho Diterima \\
\hline $\begin{array}{l}\text { Motivasi Berprestasi Tinggi dan } \\
\text { Rendah Kelas Eksperimen }\end{array}$ & 65.67 & 6.44 & 28.96 & 2.72 & Ho Ditolak \\
\hline $\begin{array}{l}\text { Motivasi Berprestasi Rendah } \\
\text { Eksperimen } \\
\text { Motivasi berprestasi Tinggi } \\
\text { Kontrol }\end{array}$ & 65.67 & 5.97 & 0.92 & 2.72 & Ho Diterima \\
\hline $\begin{array}{l}\text { Motivasi Berprestasi Tinggi } \\
\text { Eksperimen } \\
\text { Motivasi Berprestasi Rendah } \\
\text { Kontrol }\end{array}$ & 65.67 & 6.74 & 25.22 & 2.72 & Ho Ditolak \\
\hline
\end{tabular}

\section{Pembahasan}

Hasil Belajar TIK Kelompok Siswa yang Diajar dengan Strategi Pembelajaran Problem Based Learning Lebih Tinggi Dibandingkan Hasil Belajar TIK Kelompok Siswa yang Diajar dengan Strategi Pembelajaran PQ4R

Temuan penelitian berdasarkan analisis data hasil penelitian dengan anava dua arah diperoleh bahwa hasil belajar TIK kelompok siswa yang diberi pembelajaran dengan Strategi Pembelajaran Problem Based Learning lebih tinggi dibandingkan hasil belajar kelompok siswa yang diberi pembelajaran dengan strategi pembelajaran $\mathrm{PQ} 4 \mathrm{R}$ dengan nilai $\mathrm{F}_{\text {hitung }}$ 7,30 > $\mathrm{F}_{\text {Tabel }}$ 3,96. Perbedaan hasil belajar ini merupakan akibat pengaruh yang diberikan terhadap siswa melalui strategi pembelajaran Problem Based Learning dan PQ4R. Selain temuan penelitian berdasarkan analisis data hasil belajar, juga ditemukan perbedaan gairah belajar siswa selama mengikuti kegiatan pembelajaran dengan kedua strategi pembelajaran tersebut.

Pada strategi pembelajaran Problem Based Learning siswa kelihatan lebih aktif dan lebih tertantang untuk menemukan sendiri permasalahan pembelajaran TIK sehingga melalui pembentukan pengetahuan sendiri siswa dapat menemukan solusi terbaik bagi dirinya. Sesuai dengan tujuan khusus dari pembelajaran TIK seperti yang dikemukakan oleh Depdiknas (2003:4) yaitu mengembangkan kemampuan belajar yang berinisiatif, inovatif, kreatif, dan bertanggungjawab dalam penggunaan teknologi informasi dan komunikasi untuk pembelajaran, pekerjaan, dan pemecahan masalah, melalui strategi pembelajaran berdasarkan masalah (Problem Based Learning) guru dapat mengaktifkan siswa dalam pembelajaran TIK.

Strategi Pembelajaran Problem Based Learning merupakan salah satu strategi pembelajaran yang berpusat pada siswa (student centered), dimana kegiatan belajar siswa dilakukan secara aktif. Hal ini ditunjukkan dari proses pembelajaran Problem Based Learning yang disampaikan oleh Arends seperti dikutip oleh Ridwan (2015:139) mengenai tahapan kegiatan pembelajaran berorientasi strategi pembelajaran Problem Based Learning, dimulai dari guru memperkenalkan situasi masalah kepada siswa, mengorganisasikan siswa untuk belajar (membantu siswa mendefinisikan masalah), membimbing investigasi yang dilakukan oleh siswa terhadap situasi masalah yang disajikan baik secara individu maupun kelompok, membantu siswa dalam mengembangkan dan menyajikan hasil kerjanya, kemudian menganalisis dan mengevaluasi proses penyelesaian masalah 
yang telah dilakukan. Siswa diberi kesempatan terlebih dahulu untuk memahami persoalan yang diberikan, kemudian siswa mendiskusikannya dalam kelompok belajar serta melakukan investigasi bersama, setelah itu memodelkannya kembali dengan cara sendiri seraya dibimbing guru dan kemudian melakukan analisis dan mengevaluasi proses penyelesaian masalah yang telah dilakukan bersama.

Temuan penelitian ini juga sejalan dengan hasil penelitian yang dilakukan oleh Prayekti (2015) dalam penelitiannya yang menyimpulkan bahwa strategi pembelajaran Problem Based Learning (PBL) berpengaruh secara signifikan terhadap hasil belajar siswa. Siswa yang dibelajarkan dengan strategi Problem Based Learning memiliki hasil belajar yang lebih tinggi dibandingkan dengan siswa yang dibelajarkan dengan strategi PQ4R. Melalui strategi pembelajaran yang dapat meningkatkan keaktifan siswa dalam belajar teruji dapat mengoptimalkan hasil belajar siswa.

Kondisi berbeda yang terjadi dengan strategi pembelajaran PQ4R yang memfokuskan kegiatan pembelajaran melalui keterampilan membaca. Kelebihan strategi pembelajaran $\mathrm{PQ} 4 \mathrm{R}$ memang dapat mengurangi kejenuhan siswa dalam belajar melalui kegiatan membaca. Kebanyakan siswa biasanya merasa jenuh apabila dihadapkan dengan materi bacaan, akan tetapi melalui keterampilan membaca yang diterapkan melalui PQ4R memang dapat mengurangi kejenuhan tersebut. Akan tetapi, dalam pembelajaran TIK, informasi belajar yang didapat melalui buku kurang sepenuhnya dapat berkesan kuat membentuk pengetahuan siswa agar dapat bertahan lama di dalam ingatan siswa. Tingkat pemahaman siswa juga kurang dapat dibentuk melalui strategi pembelajaran PQ4R dikarenakan siswa kurang berinteraksi dengan makna belajar yang sesungguhnya dalam dunia nyata seperti yang diterapkan melalui strategi pembelajaran Problem Based Learning .

Kelebihan strategi pembelajaran Problem Based Learning dalam membangun pengetahuan siswa melalui interaksi antar siswa dan berhubungan langsung dengan permasalahan nyata mengenai makna dari informasi belajar adalah kekuatan strategi ini dalam memberikan kesan belajar yang melekat kuat dalam ingatan siswa. Oleh sebab itu, hasil belajar siswa yang dihasilkan melalui strategi pembelajaran Problem Based Learning lebih tinggi dibandingkan dengan strategi pembelajaran PQ4R.

Hasil Belajar TIK Kelompok Siswa yang Memiliki Motivasi Berprestasi Tinggi Lebih Tinggi dari Hasil Belajar TIK Kelompok Siswa yang Memiliki Motivasi Berprestasi Rendah

Berdasarkan analisis data hasil penelitian dengan anava dua arah diperoleh bahwa hasil belajar TIK kelompok siswa yang memiliki Motivasi Berprestasi Tinggi lebih tinggi dibandingkan hasil belajar kelompok siswa yang memilki Motivasi Berprestasi Rendah dengan nilai $\mathrm{F}_{\text {hitung }}=16,79>\mathrm{F}_{\text {Tabel }}=$ 3,96. Motivasi berprestasi merupakan salah satu karakteristik siswa yang memiliki pengaruh terhadap hasil belajar siswa. Temuan penelitian ini telah membuktikan hal tersebut. Bagi siswa yang memiliki motivasi berprestasi tinggi memposisikan diri sebagai pribadi yang selalu terdorong mencapai prestasi optimal dalam belajar, untuk memperoleh penghargaan tertinggi dari guru terlebih lagi untuk kepuasan diri. Oleh sebab itu, siswa yang memiliki motivasi berprestasi tinggi memiliki usahan belajar yang lebih dibandingkan dengan siswa yang memiliki motivasi berprestasi rendah. Hal ini dipertegas oleh Winkel (1997:197) yang mengartikan motivasi berprestasi sebagai kecenderungan untuk meraih prestasi dalam hubungan dengan nilai standar keunggulan.

Memperhatikan faktor motivasi berprestasi siswa dalam pembelajaran TIK sangatlah penting. Hal ini mengacu kepada salah satu tujuan khusus pembelajaran TIK seperti yang dikemukakan oleh Depdiknas (2003:4) yaitu memotivasi kemampuan siswa untuk beradaptasi dan mengantisipasi perkembangan teknologi informasi dan komunikasi. Maka oleh sebab itu, faktor motivasi berprestasi siswa merupakan faktor yang sangat penting dalam proses pembelajaran TIK guna mencapai hasil belajar TIK yang diharapkan. Temuan penelitian ini juga selaras dengan penelitian yang dilakukan oleh

Hayatsyah (2005) dalam penelitiannya menyimpulkan bahwa siswa yang memiliki motivasi berprestasi tinggi memiliki hasil belajar yang lebih tinggi dibandingkan dengan siswa yang memiliki motivasi berprestasi rendah. Siswa yang memiliki motivasi berprestasi tinggi akan selalu ingin bersaing untuk mencapai suatu tujuan dengan mengutamakan standart tertentu dengan belajar keras dan bekerja keras melakukan suatu 
pekerjaan dengan baik, serta selalu memiliki motif memilih yang terbaik demi kemajuan pendidikannya. Siswa yang memiliki motivasi berprestasi yang rendah akan menunjukkan tingkah laku belajar yang kurang responsif, yang artinya siswa tidak mau berusaha secara maksimal untuk mencapai hasil belajar yang maksimal sesuai dengan standart keunggulan.

Terdapat Interaksi Antara Strategi Pembelajaran dan Motivasi Berprestasi dalam Mempengaruhi Hasil Belajar TIK.

Berdasarkan analisis data hasil penelitian dengan anava dua arah diperoleh bahwa terdapat interaksi antara Strategi Pembelajaran dan Motivasi Berprestasi dalam mempengaruhi hasil belajar TIK dengan nilai $\mathrm{F}_{\text {Hitung }}$ kolom - baris (interaksi) lebih besar dari $\mathrm{F}_{\text {Tabel }}\left(\mathrm{F}_{\text {Hitung }}=12,64>\mathrm{F}_{\text {Tabel }}=3,96\right)$ pada taraf signifikansi 5\%. Selanjutnya, melalui uji lanjut Scheffe telah diperoleh strategi pembelajaran yang memiliki interaksi dengan Motivasi Berprestasi yang lebih positif dan signifikan terhadap hasil belajar TIK siswa.

Berdasarkan hasil analisis uji lanjut diperoleh bahwa hasil belajar TIK siswa yang memiliki Motivasi Berprestasi tinggi yang diberi perlakuan dengan strategi pembelajaran Problem Based Learning teruji lebih unggul dibandingkan dengan hasil belajar siswa lainnya. Hasil ini membuktikan bahwasanya siswa yang memiliki Motivasi Berprestasi yang tinggi akan lebih memaksimalkan hasil belajar TIK apabila didukung melalui strategi pembelajaran yang lebih membangkitkan rasa percaya diri siswa dan suasana pembelajaran yang menantang dan menyenangkan seperti yang terjadi dalam perlakuan strategi pembelajaran Problem Based Learning. Strategi pembelajaran Problem Based Learning lebih mengundang kreativitas dan motivasi belajar siswa dan hal ini merupakan kondisi yang sagat disenangi oleh kelompok siswa yang memiliki Motivasi Berprestasi yang tinggi. Mereka lebih tertantang untuk memecahkan masalah belajar dan melalui strategi pembelajaran Problem Based Learning memberikan kondisi pembelajaran dengan pengalaman nyata sehingga lebih berkesan bagi siswa dan dapat lebih bertahan lama dalam ingatan siswa.

Temuan penelitian ini sejalan dengan pendapat yang dikemukakan oleh Slameto (2009:54) mengenai faktor-faktor yang mempengaruhi hasil belajar yang digolongkan menjadi dua, yaitu (1) Faktor internal yaitu faktor yang berasal dari dalam diri peserta didik
Perbedaan karakteristik berdasarkan motivasi berprestasi ini menunjukkan perbedaan usaha belajar siswa sehingga hasil belajar yang dicapai juga turut berbeda. Siswa yang memiliki motivasi berprestasi tinggi lebih memaksimalkan usaha belajar untuk tampil menjadi yang lebih unggul.

yang meliputi dua aspek, yaitu: (a) Faktor jasmaniah seperti kesehatan dan cacat tubuh dan (b) Faktor psikologis seperti intelegensi, sikap, bakat, minat dan motivasi; (2) Faktor eksternal yaitu faktor-faktor yang yang sifatnya di luar diri peserta didik, faktor ini dibagi menjadi tiga yaitu (a) faktor keluarga seperti cara orang tua mendidik, relasi antar anggota keluarga, suasana rumah, keadaan ekonomi keluarga dan latar belakang kebudayaan; (b) faktor sekolah seperti strategi pembelajaran, kurikulum, metode belajar, tugas rumah; dan (c) Faktor masyarakat.

Dengan memadukan faktor strategi pembelajaran yang tepat untuk berinteraksi dengan karakteristik motivasi berprestasi siswa, maka diperoleh hasil belajar yang optimal. Strategi pembelajaran Problem Based Learning teruji cocok diterapkan pada siswa yang memiliki motivasi berprestasi tinggi dikarenakan kegiatan belajar yang disajikan dapat memacu semangat belajar siswa melalui permasalahan belajar yang nyata dan pembentukan pengetahuan berdasarkan cara siswa. Berikut disajikan pada Gambar 1. pola interaksi antara Strategi Pembelajaran dan Motivasi Berprestasi terhadap hasil belajar TIK siswa:

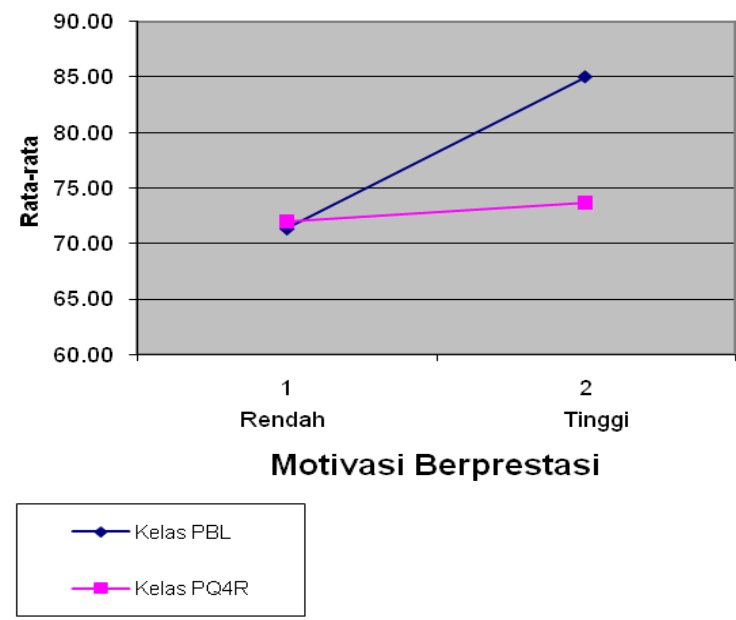

Gambar 1. Pola Interaksi antara Strategi Pembelajaran dan Motivasi Berprestasi terhadap Hasil Belajar TIK Siswa 


\section{SIMPULAN}

Berdasarkan hasil penelitian, maka kesimpulan yang dapat dikemukakan yaitu:

1. Kelompok siswa yang diajar dengan strategi pembelajaran Problem Based Learning memperoleh hasil belajar TIK yang lebih tinggi dibanding kelompok siswa yang diajar dengan strategi pembelajaran $\mathrm{PQ} 4 \mathrm{R}$

2. Kelompok siswa yang memiliki Motivasi Berprestasi Tinggi memperoleh hasil belajar TIK yang lebih tinggi dibanding kelompok siswa yang memiliki Motivasi Berprestasi Rendah.

3. Terdapat interaksi antara Strategi Pembelajaran dan Motivasi Berprestasi dalam mempengaruhi hasil belajar TIK siswa. Artinya kelompok siswa yang memiliki Motivasi Berprestasi Tinggi yang diajar dengan strategi pembelajaran Problem Based Learning memperoleh hasil belajar TIK yang lebih tinggi dibanding dengan kelompok siswa yang memiliki Motivasi Berprestasi Rendah dan kelompok siswa yang diajar dengan strategi pembelajaran PQ4R yang memiliki Motivasi Berprestasi Tinggi dan Rendah. Sebaliknya, kelompok siswa yang memiliki Motivasi Berprestasi Rendah yang diajar dengan strategi pembelajaran Problem Based Learning memperoleh hasil belajar TIK tidak signifikan berbeda dengan hasil belajar TIK kelompok siswa yang diajar dengan strategi pembelajaran PQ4R yang memiliki Motivasi Berprestasi Tinggi dan Rendah.

\section{DAFTAR PUSTAKA}

Ali, M. (2009). Pendidikan untuk pembangunan nasional. Jakarta: PT Gramedia.

Depdiknas, Puskur Balitbang. (2003). KBK (Kurikulum Berbasis Kompetensi). Jakarta: Depdiknas.

Depdiknas. (2003). Standar Kompetensi Mata Pelajaran TIK. Jakarta: Depdiknas

$\begin{array}{cr}\text { Depdiknas. (2004) Pedoman } & \text { Khusus } \\ \text { Pengembangan } & \text { Silabus } \\ \text { Berbasis Kompetensi (SMA) } & \text { Mata } \\ \text { Pelajaran TIK. Jakarta: Depdiknas }\end{array}$

Depdiknas. (2004). Sistem Penilaian. Jakarta: Depdiknas. Dirjen Dikti Depdiknas. (1981). Evaluasi Program Edisi Revisi IV. Jakarta: Rineka Cipta.

Depdiknas.(2003). KBBI, Edisi Ketiga.Jakarta: Balai Pustaka.

Dimyati, Mudjiono. (2014). Belajar dan Pembelajaran. Jakarta: Rineka Cipta

Djaali.(2008). Psikologi Pendidikan. Jakarta: Bumi Aksara

Haryono. (2005). Profesionalisas Pembelajaran TIK di Sekolah, Seminar Nasional. Semarang

Hiyatsyah.(2005) Pengaruh Strategi Pembelajaran dan Motivasi Berprestasi terhadap Hasil Belajar Kimia Siswa MAN 2. Medan: Tesis PPs Unimed. Tidak diterbitkan

Khoe, Yao Tung. (2015). Pembelajarandan Perkembangan Belajar. Jakarta: Indeks

Prayekti. (2015). Pengaruh Strategi Problem Based Learning Versus Ekspositori dan Motivasi Berprestasi Terhadap Hasil Belajar TIK Siswa SMA Kelas X, Jurnal Pendidikan Ilmiah, 3 (2)

Ridwan, A.. (2015) Pembelajaran Saintifik untuk Implementasi Kurikulum 2013. Jakarta:Bumi Aksara.

Slameto. (2009). Belajar dan Faktor-faktor yang mempengaruhinya. Jakarta: PT. Asdi Mahasatya

Trianto. (2007). Model-model Pembelajaran Inovatif Berorientasi Konstruktivistik. Jakarta: Prestasi Pustaka Publisher

Winkel, W.S. (1997). Psikologi Pengajaran. Yogyakarta: Media Abadi

Wulandari, Bekti. Dwi Sarjono, Herman. (2013). Pengaruh Problem Based Learning Terhadap Hasil Belajar Ditinjau Dari Motivasi Belajar PLC di SMK. Jurnal Pendidikan Vokasi: 180. 